\title{
Az első magyar légitámadás déli szomszédunk ellen - 1919
}

A szerb-horvát-szlovén határszakaszon - habár a határ túloldalán nem mutattak Magyarország ellen irányuló katonai aktivitást - a Kaposvárra települt 1. repülőszázad volt hivatott felderítései révén informálni a hadsereg-főparancsnokságot a fennálló helyzetről. ${ }^{1} \mathrm{Az}$ egység április 8-tól az 1. hadosztály, majd május 8-tól kezdve a II. hadtest alárendeltségében tevékenykedett ${ }^{2}$ a következő feladattal: „felderíteni a.) a Csáktornya valamint Pécs környékén végbemenő csapatmozgásokat, b.) a Steinbrück-Zágráb-Gyékényes környékén és a PragerhofCsáktornya vasútvonalon állitólag felvonuló csapatszállítmányokat. E célra a Csáktornya és Pécs környékét naponként, Steinbrück-Zágráb és Magyarország határa közötti részt hetenként kétszer derítse fel."

1. ábra. Légi felvétel Koprivnica külvárosáról 1919-ben. Kivehető a két sátorhangár, mellette a téglagyár (R. Čopec gyüjteményéből)

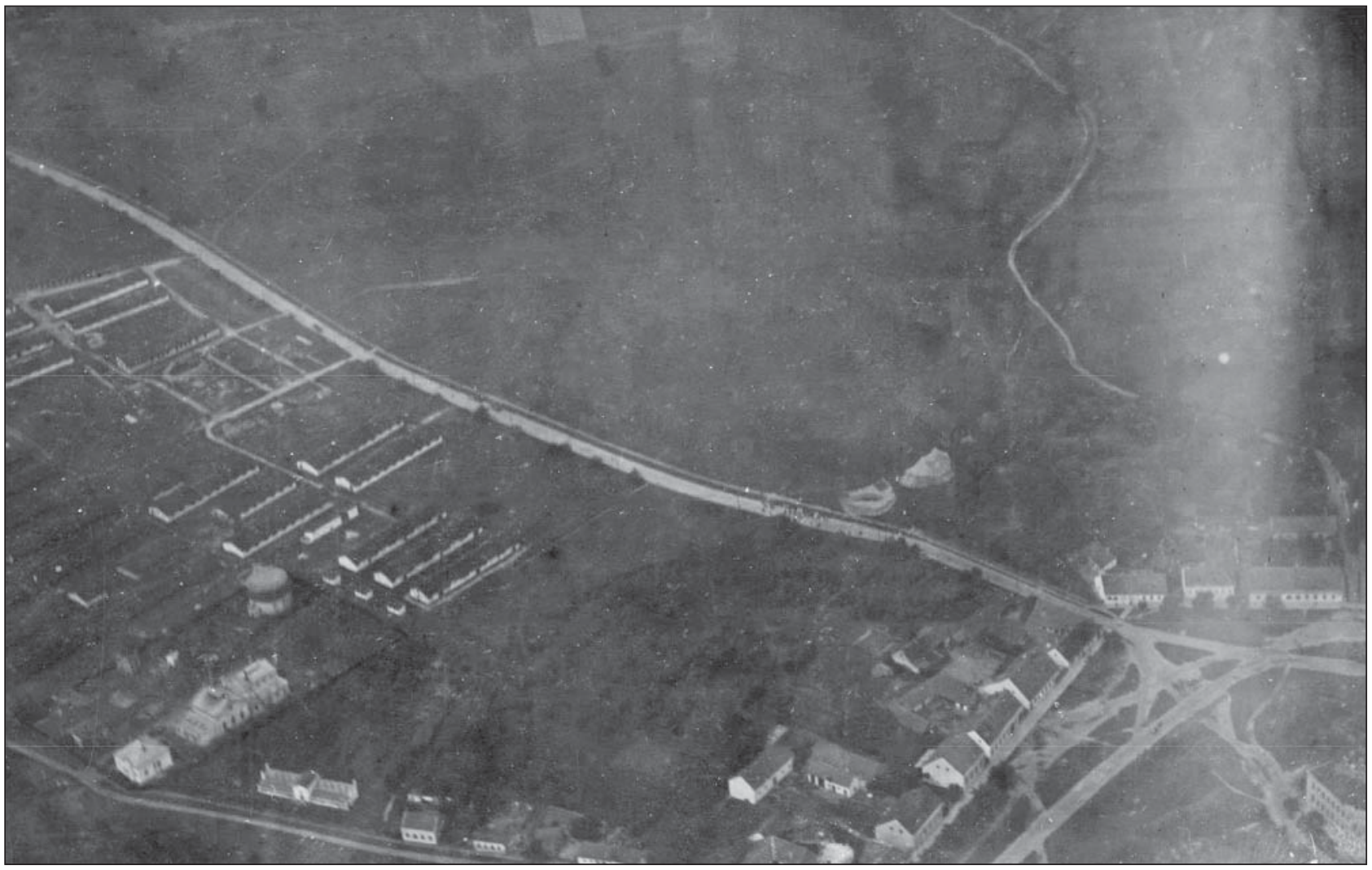

ÖSSZEFOGLALÁS: Az önálló magyar repülőcsapatok történetének első harci bevetései a Tanácsköztársaság és a Vörös Légjáró Csapatok időszakához tartoznak és bár ezen akciók elsősorban a román és csehszlovák frontszakaszok felett zajlottak, az új államalakulatként létrejött Szerb-Horvát-Szlovén Királysággal is elöfordult súrlódás. E kivételes esemény körülményeit veszi a jelen tanulmány vizsgálat alá.

KULCSSZAVAK: I. világháború, Tanácsköztársaság, magyar repülőcsapatok, UFAG C.I közelfelderitő repülőgép, Aviatik D.I vadászrepülőgép
ABSTRACT: The first combat sorties in the history of the independent Hungarian air groups were flown during the Hungarian Soviet Republic and when the Red Air Going Groups existed. Although these actions have been carried out mainly above the Romanian and Czechoslovakian front line section, friction also happened with the Kingdom of Serbs, Croats and Slovenes formed as a new entity. This study examines circumstances of this uncommon event.

KEY WORDS: World War I, Hungarian Soviet Republic, Hungarian Air Groups, UFAG C.I close reconnaissance aircraft, Aviatik D.I fighter aircraft 
1. táblázat. A magyar repülőgépek konkrétan a kaposvári század állományából, valóban több alkalommal jártak felderítési feladatokkal - korábbi magyar nevén - Kapronca felett, ezen bevetések közül 1919. júniusig az alábbiak ismertek:

\begin{tabular}{|c|c|c|l|}
\hline Dátum & Pilóta & Megfigyelő & \multicolumn{1}{c|}{ Útvonal } \\
\hline IV. 30. & Ruttkay Károly & Rotaridesz Valdemár & Kaposvár-Kapronca-Novigrad-St. Georges-Kaposvár \\
\hline V. 9. & Pranger Adolf & Sziszel Ferenc & Kaposvár-Légrad-Kapronca-Kaposvár \\
\hline V. 10. & Pranger Adolf & Krakauer & Kaposvár-Gyékényes-Kapronca-Zágráb-Kaposvár \\
\hline V. 12. & n.a. & n.a. & Kaposvár-Kapronca-Bracs-Kaposvár \\
\hline V. 16. & n.a. & n.a. & $\begin{array}{l}\text { Kaposvár-Kapronca-Kőrös-Varasd-Csáktornya-Barcs-Dráva- } \\
\text { Muraköz-Szigetvár-Apatin-Kaposvár }\end{array}$ \\
\hline
\end{tabular}

A század kezdetben UFAG C.I-es közelfelderítő gépekkel rendelkezett, ám az előírt nagyobb távolságú bevetésekhez a Hansa-Brandenburg C.I típusra volt szükségük, amelynek néhány példánya május végén meg is érkezett az egységhez. Emellett június elején két MÁGgyártású ${ }^{4}$ Aviatik D.I vadászgépet is kaptak és attól függetlenül, hogy a volt repülőtisztek kapcsán, valamint a szűkös repülőtér miatt komoly problémák is adódtak, az alakulat képes volt ellátni a rábízott feladatokat.

A világháború befejeződésével a déli szláv állam is az osztrák-magyar repülőcsapatok maradványaiból, pontosabban a horvát, szlovén és montenegrói területeken lefoglalt repülőanyagokból igyekezett felállítani saját repülőerő fegyvernemét. ${ }^{5}$ Ez a körülményekhez képest sikeresen zajlott és már 1918-ban bevethető alakulatokat mondhattak magukénak, igaz, használható repülőgépekben és különösen üzemanyagban komoly hiányok mutatkoztak. A Tanácsköztársaság harcaiba nem avatkoztak be, területi igényeik ugyanis elsősorban a szlovénoknak voltak Karintiában. Emiatt az osztrákokkal kialakult összetűzés során a két szlovéniai - Ljubljanában és Mariborban állomásozó - repülőszázad vett részt a harcokban. ${ }^{6}$

Az 1919. március 21-én beállt hadiállapotot követően azonban a horvátországi Zágrábban települt 1. repülőszázadnak (1. Ljetačka satnija) szintén adódtak feladatai - és veszteségei is. 1919. április 26-án az egyik gépük, gyakorlórepülés során kényszerleszállást hajtott végre magyar területen és a legénység, Alfons Veljačić százados és Belovec megfigyelő fogságba esett. ${ }^{7} \mathrm{~A}$ század egy része hamarosan átköltözött Koprivnica mellé, a május 11-én kelt parancs szerint három repülőgépet kellett

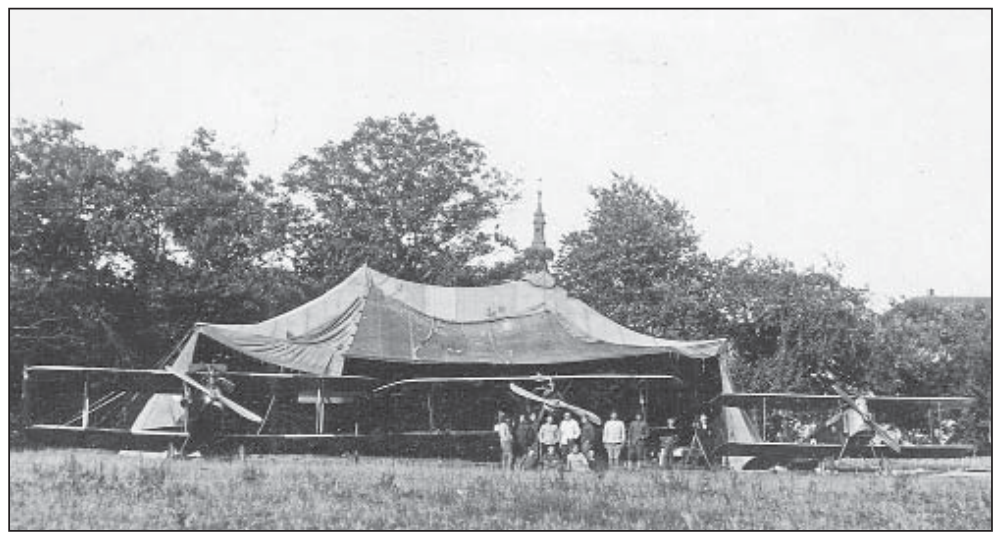

2. ábra. Repülőgépek és személyzet Koprivnica repülőterén. Balról a negyedik Mato Švarc hadnagy századparancsnok, az ötödik Dragutin Balzareno, szintén volt osztrák-magyar pilóta (R. Čopec gyüjteményéből)

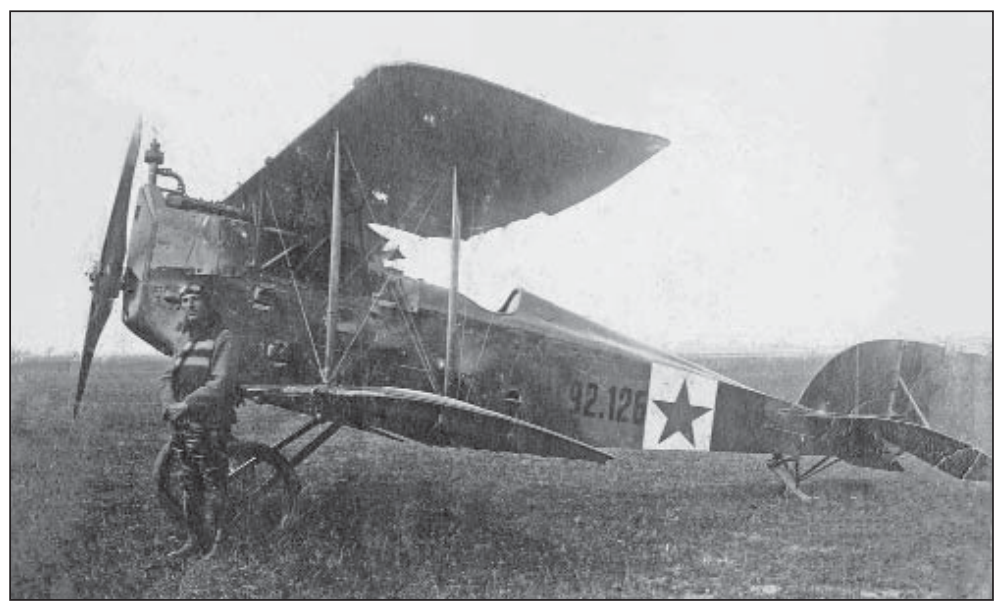

3. ábra. Aviatik D.I-es vadászgép valamikor 1919. május-júniusban, Szombathelyen (Tálosi Zoltán gyüjteményéből) ide telepíteniük. Az átirányítás közvetlen előzménye az volt, hogy 1919. április 30-án magyar repülők propagandaanyagot szórtak le a városra - szórólapokat a bolsevizmus elfogadására, valamint Vörös Zászló című újságokat. (Horvát levéltári adatok szerint hasonló akciókat hajtottak végre magyar gépek Legrad, Đelekovec és Ludbreg felett május 9-én, június 15-én és 21 -én is.) ${ }^{8}$

A koprivnicai átköltözés elég vontatottan haladt, több ok miatt is. Az első repülőgép május 15-én startolt, de visszatért, mivel lehetetlen volt leszállni a várost borító felhők miatt. Másnap szintén elindult egy gép Zágrábból Kopriv-

nicára, de a felszállásnál összetört és a legénysége megsérült. Végül május 17-én érkezett meg az első „fecske”, majd a következő napon egy vadászgép is csatlakozott hozzá, amely korábban Ljubljanából repült át Zágrábba.

$A$ város mellett egy ideiglenes repülőteret alakítottak ki a különítmény számára, a repülőszemélyzet feladata pedig egyrészt a határterület megfigyelése volt a Dráva mentén Barcstól Legradig, és esetenként Međimurje régió felderítése, másrészt a határon történő magyar átrepülések megakadályozása. Az egység parancsnokának Mato Švarc hadnagyot nevezték ki, ő korábban az osztrák-magyar re- 


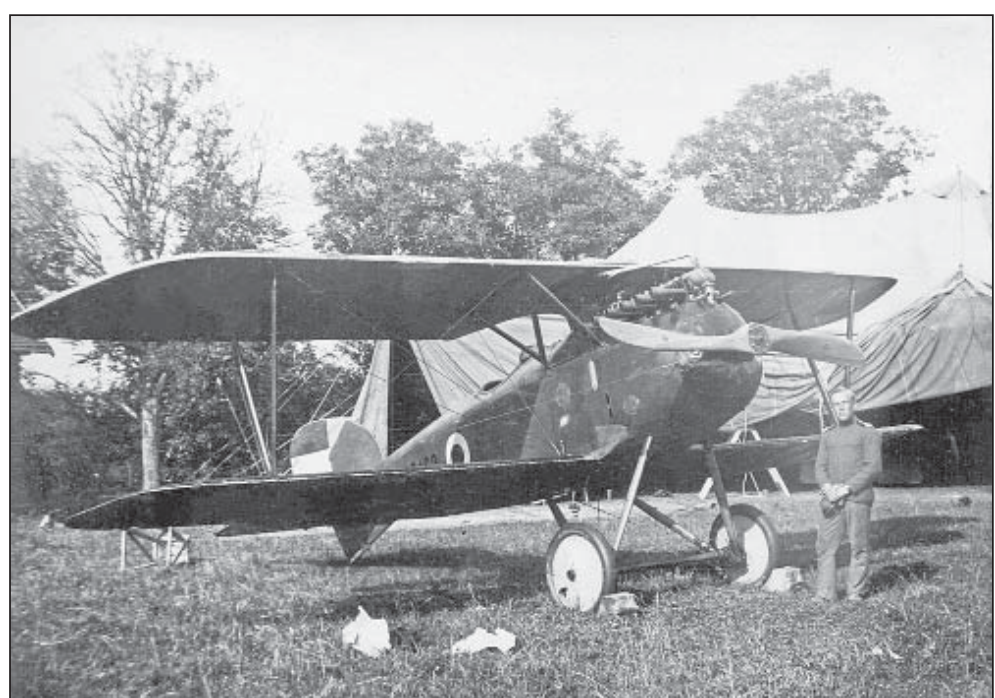

4. ábra. A 253.163 jelú Albatros D.III (Oef) vadászgép Koprivnica repterén 1919-ben, előtte Nikola Sekulić örmesterrel (R. Čopec gyüjteményéből)
A támadás - mivel különösebb kárt nem okozott - a koprivnicai különítmény életében sem eredményezett fennakadást. Az alakulat repülői két felderítő bevetést hajtottak végre június 16-án, a második után a kétüléses gép a zágrábi bázisra tért vissza. Ugyanezen a napon azonban egy másik vadászgép is csatlakozott a különítményhez. A magyar géppuskagolyóknál jóval nagyobb gondot jelentett az üzemanyaghiány, hivatalos beszámoló szerint ugyanis, emiatt az alakulat július második fele és augusztus első hete között egyáltalán nem végzett repülést. Az ekkor rendelkezésre álló 106 kg-nyi benzint „végszükség” esetére tartogatták.

Időközben, július 12-én a kaposvári századot Kecskemétre rendelték a tiszai átkelés támogatására, ${ }^{12}$ Hoffart Jánost pedig az utolsó repülőképes Aviatik D.I-es vadászgéppel (92.131) Ongára irányították az ottani harci repülőerők megerősítésére. Így végképp elmúlt annak veszélye, hogy a déli-délnyugati határt magyar repülőgépek lépjék át.

pülőcsapatok berkeiben repült, akkoriban Matthias Schwartz néven. Maga a reptér egy nyílt mezőn helyezkedett el, amely Ljudevit Toplak, a híres téglagyáros tulajdonában állt.

Stjepan Burazović véleménye szerint a különítmény munkája nem volt igazán harci jellegü, mivel a határ ezen szakaszán nem zajlottak igazi összecsapások. Ennek ellenére 1919. május-június hónapokban több bevetést hajtottak végre, az elsőt május 29-én, miután feltöltötték a 150 méter széles mezőn tátongó lyukakat, ezzel lehetővé téve a biztonságos fel- és leszállást. Másnap próbarepülést végeztek, majd a különítmény vadászgépe teljesített harci feladatot.

A kaposváriak június 4-én fedezték fel az újonnan felállított repteret. 14:15-kor Ruttkay Károly pilóta és Bányai József emelkedett levegőbe a 169.195 jelű Hansa-Brandenburg C.I-es felderítőgéppel, de Kaposvárról Gyékényes-Kapronca-Csáktornya-Alsólendva útvonalon repülve, 16:45-kor Répáson (ma: Repaš, Horvátország) leszállni kényszerültek motorhiba miatt. A végül másnap délután leadott jelentés legfontosabb megállapításai a következők voltak: „Kapronczán az utcai élet nagyon élénk. Különösen a helységet átvágó széles utcán. A város déli részén repülötér, amelynek hossza $1 \mathrm{~km}$, szél. $600 \mathrm{~m}$. A repülötéren óriási ponyvahangár, amely ca. 15 gép[et] tud befogadni. Mellette óriási deszkabarakk. A ponyvahangár előtt 2 ember volt látható, de ruházatukat nem lehetett megismerni." 10

Bár a rendelkezésre álló adatok és fotók alapján a repülőtérre vonatkozó megállapítások helyenként túlzóak, a reagálás nem sokáig váratott magára. Június 15-én 18:00kor két magyar vadászgép támadta meg a repteret, de a sátorhangárokban lévő két gép sértetlen maradt. A támadók közül az egyik 150-200 méteres magasságból géppuskázta a hangárokat, mintegy 150 lövést leadva, majd távozásukat követően a városra és környékére szórtak propaganda anyagokat. A helyi jelentés szerint a földről légvédelemre felállított géppuskákkal tüzeltek a támadó magyar repülőkre. A vakmerő akció kivitelezőinek azonosítása nem okoz különösebb nehézséget, annak ellenére, hogy magyar dokumentum egyáltalán nem említi az esetet. Kaposváron ekkoriban ugyanis két Aviatik D.I vadászgép állt szolgálatban, 92.131 és 92.132 jelzéssel, ezeket pedig kizárólag Hoffart János és Ruttkay Károly repülte. ${ }^{11}$
A következő összecsapásra a jugoszláv légierővel 1921 áprilisában került sor, IV. Károly, magyar király visszatérési kísérlete alkalmával. Akkor a zágrábi 4. repülőszázad gépei ismét Koprivnica és Bjelovár reptereiről kerültek bevetésre.

\section{JeGYZETEK}

1 A kaposvári repülőalakulat történetéhez lásd: Czirók Zoltán: A kaposvári repülőszázad (1918-1919). Somogy megye múltjából, 2007. 247-256. o.

2 Hadtörténelmi Levéltár (továbbiakban: $\mathrm{HL}$ ), Magyar Tanácsköztársaság (továbbiakban: MTK) iratai. 7848/eln. IV. 8 1919., 10756/eln. 37. o. 27. d.

3 HL MTK iratai. 14. sz./hdm. 97. d.

4 A mátyásföldi Magyar Általános Gépgyár Fokker D.VII és Aviatik D.I típusú vadászgépek gyártását, illetve összeszerelését végezte ebben az időben.

5 Természetesen a világháborúban küzdő szerb repülőszázadok alkották a szerb-horvát-szlovén repülőcsapatok magját, ám ezek a későbbiekben is elsősorban szerb területen települtek.

6 Gustav Ajdič - Zoran Jerin: Letalstvo in Slovenci 2. Ljubljana, Založba Borec - Mladika, 1990. 10-13. o. A szlovéniai egységek Letalska stotnija Ljubljana és Letalska stotnija Maribor néven tevékenykedtek.

$7 \mathrm{Az}$ eset érdekessége, hogy magyar dokumentumok szerint a tapasztalt háborús pilóta, Veljačić százados, a világháború végén az egyik aradi kiképző alakulat, a 9. repülőpótszázad (Fliegerersatzkompagnie Nr. 9) parancsnokaként úgy nyilatkozott, hogy mindenképpen a magyar hadsereg kötelékében akar szolgálni. HL, Polgári Demokratikus Forradalom iratai. 125/Lü 1918. 29. d.

8 A tanulmányban felhasznált és hivatkozott valamennyi adat és információ, amely horvát levéltári forrásokon alapul, Josip Novak, horvát repüléstörténeti kutató munkáját dicséri, aki nagylelkủen a rendelkezésemre bocsátotta őket - ahogy a vonatkozó fényképekhez is az ő közvetítésével jutott a szerző. Ezúton is szeretném kifejezni hálás köszönetemet a segítségéért.

9 HL MTK iratai. Repülések nyilvántartása. (A 4. repülőosztály áprilisi és az 1. repülőszázad májusi repülési kimutatásai.) 28. d.; 512/213. hdm., 517/1. hdm. 81. d.

10 HL MTK iratai. 605/206. hdm. 63. d.

11 Mindkét magyar pilóta szolgált a Monarchia repülőcsapatainál. Ruttkay 1919. július 2-án, Kaposváron zuhant le a 92.132 számú vadászgéppel, a pilóta a baleset során életét vesztette.

12 HL MTK iratai. 713/202 hdm. 78. d. 